\title{
Integrative Islamic Personality Inventory: Development and Validation
}

\author{
Nik Ahmad Hisham Ismail", Mustafa Tekke**
}

\begin{abstract}
With the growing awareness of the need to integrate modern psychological approaches with Islamic values and practices, there is a need among Muslim psychologists and other behavioral scientists for an instrument capable of capturing the major elements of the Islamic personality. Therefore, the purpose of this study was to develop and take the first steps in the validation of the Integrative Islamic Personality Inventory (IIPI), which is a newly developed measurement. With regard to content validity, 64 items were generated based on the judgments of a panel of experts. Fifty-seven respondents completed the preliminary instrument. The inventory demonstrated excellent reliability and strong internal validity. In the next phases, the inventory will be further validated and calibrated based on different psychometric standards and models.
\end{abstract}

Keywords: content validity, personality, Islam, item development, inventory

\section{Introduction}

The process of Islamization of psychology depends, among others, on the availability of good quality instruments for assessing different psychological domains and characteristics. In his widely acclaimed book, The Dilemma of Muslim Psychologists, Malik B. Badri (1979) argued for the need for Muslim psychometricians to undertake the development of valid and reliable instruments that can be used with Muslim clients. This is especially important since most of the psychometric instruments

\footnotetext{
* Professor and Dean, Kulliyyah of Education, International Islamic University Malaysia, Email: nikahmad@iium.edu.my

** Postgraduate researcher, Kulliyyah of Education, International islamic University Malaysia. Email: mustafatekke@gmail.com
} 
available today are created by non-Muslims, for non-Muslims, based on the experiences of non-Muslim individuals and communities.

At present, there is a need for an Islamic related instrument capable of capturing the major elements of the Islamic personality. Sound psychometric practices demand that the creator of an instrument explains and determines the relevancy and the representativeness of content domain it supposes to cover (Reynolds, Livingston, and Wilson 2006). This requires the developers of this integrated Islamic personality instrument to begin with an organic definition and concept for personality from the Islamic perspective.

To the best of our knowledge, most of the attempts at examining personality among Muslim populations have relied almost entirely on Islamic theology (Abu-Raiya \& Pargament, 2011). Such an approach of adaptation, however, has great limitations in understanding personality from the perspective of specific religious traditions and their unique worldviews (Smither \& Khorsandi, 2009). Specifically, existing developed instruments that have been used to measure personality or religiosity of Muslim populations do not take into account the integration of the Islamic perspective and Western philosophy. The limited scope of current Islamic measurement conceptualization has led to major gaps in measurement of personality. To date, there are instruments related to the empirical psychology of Islam to measure the religious constructs such as moral values/ethical principles, mysticism, afterlife motivation, attitudes, obligation, practices, coping methods conversion, and beliefs (Abu-Raiya \& Hill, 2014).

The purpose of this study, therefore, was to develop and conduct the initial validation of an Integrative Islamic Personality Inventory (IIPI). It discusses the process of item development, content validity, item refinement and estimation of reliability. It highlights the procedures applied to establish the reliability and validity of the proposed instrument.

\section{Instrument development}

Prior to the development of the IIPI, the conceptualization stage has been done accordingly based on Western and Islamic perspective. In so doing, the researchers have made extensive review of literature from various resources and previous researchers related to both Western and Islamic sources, which have substantial and relevant dimensions 
of personality. In addition, the indicators of personality may suit the characteristics of Islamic personality of young people.

The construction of the IIPI initially began with a collection of statements underlying the four Islamic fundamental aims of Islam, initiated by one of the Islamic scholars from Turkey, Said Nursi. The constructs were drawn from Tawhid (Divine unity), Hashr (Resurrection), Nubuwwa (Prophethood) and Ibadah (Worship) as indicatives of the concept of integrative Islamic personality.

According to Nursi, these four fundamental aims or main elements of Islam are available in the whole Quran, so they are well manifested in every surah of Holy Quran. Here, we will briefly explain each constructs.

\section{Tawhid}

Tawhid comprises "the essence and spirit of Islam, purpose of life and the most fundamental truth in Islam" (Nursi, 1923/2001, p. 235). It is belief of an individual that every world is administered, sustained, and governed directly through Almighty God and there is no way has $\mathrm{He}$ any partner or assistant in His Godhead or in His Dominicality or in His sovereignty, called true affirmation of Tawhid. In other words, Tawhid is acceptance of one Creator in one's heart. In Islamic view, the principle of Tawhid must be guide of Muslim`s life (Al-Faruqi, 1992).

\section{Hashr}

Hashr is defined as the great gathering after end of life and the place called Mahsher (Garzanli, 2011). It is viewed that this world is subject to annihilate after completion of its fixed term of life like that of other animate and inanimate things. This is specifically called as "Qeyaamah" (Doomsday). According to Nursi, belief in the hereafter enables an individual to show completely sincere respect, love, loyal, and compassion for others, are and disregard each other's faults respectively. In addition, reward and punishment are another point to consider the fact of death after life; there must therefore be a supreme tribunal in another realm to reward the good and punish the bad who mock God's rule (Nursi, 1930/2003). 


\section{Nubuwwa}

Nubuwwa, in brief, is defined as the bearer of the God's commands to the humanity (Hassan, 2014). Therefore, institute of prophethood in Islam has a special status and significance in order to remind a Muslim individual to worship Allah and lead a virtuous life based on His teachings and guidance. In other words, prophets are necessary for conveying God's instructions and guidance to Muslims in their daily practical life.

\section{Ibadah}

Ibadah is described as the total obedience to the commands of Allah (An-Nabahani, 1995; Ismail, Tekke, Othman, \& Al-Hafiz, in press; Tekke, Ismail, Adnan, Othman, 2015) and adherence to the teachings of the Prophet (Saritoprak, 2003). According to Nursi, Ibadah can be divided into two kinds, positive and negative (1934/2002). Positive means is normal and regular ones such as praying and fasting. As for negative worship, this is actually the experience of individuals involve misfortune or sickness, understand their own impotence and weakness so that they seek Creator's Compassion and look for His Mercy, and thus offer a pure form of Ibadah. This sort of circumstance helps a person feel patiently, think of the spiritual reward and offer thanks to the Creator (Nursi, 1930/2003). Therefore, this understanding of Nursi to Ibadah is reflected on the item statements.

In addition to this, researchers partially referred the understanding of humanistic psychology on personality while developing item statements. In this sense, we considered the self- theory of Carl Rogers; positive regard, self-worth, self-image, and self-ideal. As for his self-theory, it is greatly consistent with traits in Islam that it can be interpreted that the one who is striving to know oneself against his nafs (soul), meaning that true knowledge of the self would lead one to closeness with the Creator. Ismail and Tekke (2015) pointed out the importance of humanistic psychologists that "they have a tendency to have an optimistic point of view on human behavior and concentrate on the capacity of individuals to think intentionally and soundly, to control their biological urges, and to accomplish their maximum capacity" (p.34). This study, thus, attempted to reflect the understanding of West and Islam on personality accordingly by initiating a new inventory. 


\section{Item Development of Integrative Islamic Personality Inventory (IIPI)}

This initial phase is the most critical endeavor that would determine the sufficiency of references to support this study. Most importantly, this procedure represents the foundation and facilitates the whole development of the instrument of the research.

To begin this, as a new measure of IIPI, it referred to an adapted item pool of 560 (e.g., Muslim Attitudes Toward Religion Scale, The Religiosity of Islam Scale, Muslim Attitudes Toward Religion Scale and Attitudes Toward Islam Scale) and over 1000 (Q-Methodology by Stephenson,1953) items as first draft of the instrument. Wherever possible, all questions and statements generated for item pools were included rather than only those that were selected for the final version of the instrument. Items were screened for inclusion on the basis of the identified characteristics of personality. However, more general statements concerning personality through Western and Islamic perspective also were included to obtain additional items that might be relevant to the research objective. The researchers reduced duplicative items determined to be identical in phrasing or basic intent by discarding one or more items. Finally, seventy-one items were reworded to minimize any particular integrative Islamic personality.

However, items with useless redundancy may contribute to the false statement in psychometric theory, whereby increasing internal consistency estimates beyond a certain point does not enhance validity (Netemeyer, Bearden, \& Sharma, 2003). Consistently, only a reliable and valid instrument could endorse credible and quality research findings (Hair, Black, Babin, \& Anderson, 2010). It is, therefore, essential to conduct a rigorous content validity, as well as full-scale reliability tests for all the items of the instrument. Psychometrics has emerged as a methodological paradigm in its own right. Duncan (1984) supported this argument with three examples of the impact of psychometrics: (a) the widespread use of psychometric definitions of reliability and validity, (b) the popularity of factor analysis in social science research, and (c) the adoption of psychometric methods for developing scales measuring an array of variables far broader than those with which psychometric concepts was initially concerned (p.203, cited in DeVellis 2003). There 
followed is as the step applied in the validation and other procedures leading to establishing sound psychometric properties of the instrument.

\section{Item Validation of Integrative Islamic Personality Inventory (IIPI)}

The item validation of the IIPI is examined in two stages: one focuses on obtaining content validity evidence, and face validity evidence of the IIPI through expert and a pilot study, the other one further entails administering the inventory to an undergraduate sample to examine the construct validity of the IIPI via several evidential procedures. In this study, we investigated the former validation process on 71 items respectively.

\section{Content Validity}

McIntire and Miller (2007) argued that content validity requires series of experts or professionals in that particular field or content to evaluate and rate their agreements how essential of the validity of the content on each items in the instruments which also based on the operational definition by the researcher, it is imperative to eliminate unimportant and unclear items. Extending the significance of content validity, proposed new constructs of Tawhid, Nubuwwa, Hashr, and Ibadah are beneficial to undergone more rigorous examination respectively. The content validity of the IIPI has been determined by the experts in the related field to examine the appropriateness and feasibility of items specified for each construct of the instrument as proposed by Creswell and Clark (2011).

Therefore, five experts have been assigned to give comments related to the usefulness of each item whether it is in accordance with the operational definition determined by the researcher. According to Netemeyer and colleagues (2003), five experts are moderately adequate to proceed evaluation process. Experts, presented in Table 1, associated with the field of psychometric measurement have been contacted through personal correspondence and electronic mail. They received a preliminary copy of the IIPI, blueprint of IIPI, and operational definition of constructs of IIPI: (a) to evaluate each item for clarity, coherence, consistency, and conciseness, and (b) to evaluate the relevancy of each item to the measurement of integrative Islamic personality, and (c) to indicate ways of "tapping the phenomenon" that failed to have been included (DeVellis, 2003). In addition to this, each item has also been 
reviewed to determine if it was reflective of the subscale in which it was placed and if not, to define which, if any subscale, it would be better fit. The experts determined content validity, and returned their comments and suggestions.

Table 1 Distribution of Expert Panel Table

\begin{tabular}{rllll}
\hline No & Gender & Qualification & Specializaiton & Country \\
\hline 1 & Female & Assoc. Prof. & Education & Malaysia \\
2 & Female & Assoc. Prof. & Education & Malaysia \\
3 & Male & Professor & Education & Malaysia \\
4 & Male & Assist. Prof. & Science & Turkey \\
5 & Male & Assist. Prof. & Education & Turkey \\
\hline
\end{tabular}

Expert suggestions

Having expert review items pool can confirm or invalidate definition of the phenomenon (DeVellis, 2003). In this sense, items are retained if they don't receive negative feedback from the experts. Items are reworded if experts provide a clearer, more economical revision of the item. If an expert identifies an ambiguous word or concept within the item, it is reworded or discarded. Adjustments are also sought if experts indicate that the item would provide little discrepancy in how subjects respond. Expert suggestions are not applied if the suggested items require agreement or disagreement with multiple concepts. Considering all these assumptions, a complete listing of original pool of 71 items, the decision related to each item, and the reasoning for the decision is provided in Table 2.

Table 2 Decisions based on Expert Revisions

\begin{tabular}{cll}
\hline Original Item & $\begin{array}{ll}\text { Decision Regarding } \\
\text { Item }\end{array}$ & $\begin{array}{l}\text { Reason- } \\
\text { ing }\end{array}$ \\
\hline & Tawhid &
\end{tabular}

1-I am very convinced that if we gather all Remained the Same EA peoples` effort together, they cannot create even a fly.

2-I believe that Allah (SWT) is eternal. Remained the Same EA 3-I believe in the Oneness of Allah and Remained the Same EA there is no resemblance like Him. 
4-I always remember everything in the heavens and the earth belongs to Allah.

Remained the Same EA

5 -I realize that Allah is severe against

Discarded

ES

disbelievers due to their denial.

6-In general, I start everything with the

Remained the Same EA names of Allah as an example, bismillahirrahmanir- raheem.

7-I have so much to be thankful in my life due to Allah's mercy.

8-I know that Allah (SWT) loves all of us regardless of race, ethnicity and colour.

9-I believe that Allah (SWT) always speaks to me through my heart.

I know that Allah $\quad$ EW (SWT) loves all of us and his creations regardless of race, ethnicity and colour.

I believe that Al- $\quad$ EW lah (SWT) always inspires me through my heart.

10-I strongly believe Allah`s presence at Remained the Same all time.

11-Knowing Allah is nearer than my ju-

Discarded ES galar vein is very assurance.

12-I feel that Allah's domincality surrounds the universe.

Discarded ES

13-I surely acknowledge that Allah is crea-

Discarded

ES tor of everything and creating is very easy for Him.

14-I believe that Allah (SWT) is Almighty.

Remained the Same

EA

Hashr

15-I believe that If I denounce Qur`an

I believe that If I

ES

commands, I will go to Hell.

denounce Allah`s $+\mathrm{EW}$ commands, I will be among the transgressors.

16-I feel frightened when I know the earth is shaken with final earthquake in the

I feel frightened ES doomsday. when I read verses about the doomsday. 
17-I feel that people would not like me if they knew my sins.

18-I believe that Hell is a fair punishment for a sinner.

19-I believe that I will be judged in accordance with my evil doings.

20-People sometimes tell me that I am too much focusing on this world.

21-I do all good deeds as preparation to Hereafter.

22-I am thankful to Allah for all He has done for my parents and friends.

23-I am aware that I'm a person of worth, Remained the Same at least created perfectly by Allah.

24-I will be judged in accordance with my Discarded good deeds.

25-I feel that Allah hears my supplications. Remained the Same

26-I believe that everyone will receive the Discarded record of his deeds in the hereafter.

27-I know where I came from, who I am and where I'm going in the eyes of Allah (SWT).

28-I have no doubt that Allah (SWT) created me from nutfah (mixed water).

29-My every action will be shown to me in the hereafter.

30-I strongly believe that Allah (SWT) will revive rotted bones.
EW would not like me if they knew my bad deeds.

Remained the Same EA

I believe that I will EW be judged fairly in the hereafter in accordance to my doings.

People sometimes ES tell me that I am too $+\mathrm{EW}$ materialistic.

Remained the Same EA

Discarded ES

EA

ES

EA

ES

Discarded

ES

Discarded

ES

EW one will be shown of his/her deeds in the hereafter.

ES 
31-It doesn 't much matter for me what people believe as long as they are good.

32-I certainly have a faith that Allah will resurrect the dead.

33-I believe that I will return to Allah (SWT) one time.

34-I always remember that the night and day alternatively created for me on time.

35-I believe that death is beginning of life in the hereafter.

36-Knowing the sun and moon are created to serve human beings in the world makes me feel happy.
It doesn `t matter

for me what one believes as long as he/she is good.

I certainly have a faith that all dead souls will be resurrected in the hereafter.

I believe that everyone will return to Allah (SWT) one day.

I always believe that ES there is a miracle in the creation of night and day.

Remained the Same EA

I believe all creations

EW such as stars, human, animal, plants and others are created to compliment each other in this life.

\begin{tabular}{lll}
\hline \multicolumn{1}{c}{ Nubuwwah } & \\
\hline $\begin{array}{l}\text { 37-Prophet Muhammad (SAW) reflects } \\
\text { human and angelic values. }\end{array}$ & Discarded & ES \\
$\begin{array}{l}\text { 38-Prophet Muhammad (SAW) is the last } \\
\text { Prophet of the universe. }\end{array}$ & Discarded & ES \\
$\begin{array}{l}\text { 39-I ascertain that Quran is book of Allah } \\
\text { (SWT) }\end{array}$ & Discarded & EW + \\
$\begin{array}{l}\text { 40-I follow the Prophet Muhammad`s } \\
\text { teachings and traditions to show my sin- } \\
\text { cere love to Allah (SWT). }\end{array}$ & $\begin{array}{l}\text { I follow the Prophet } \\
\text { ings and traditions }\end{array}$ & ES \\
$\begin{array}{l}\text { 41-I am aware that Al-amanah (trust and } \\
\text { responsibility) is given to me as vicege- } \\
\text { rency of Allah on earth. }\end{array}$ & Discarded & ES \\
& &
\end{tabular}


42-I firmly believe that all revelations and Remained the Same EA messages of the Prophets came from Allah (SWT).

43-I believe that Allah (SWT) sent the

Remained the Same

EA

same messages to all Prophets.

44-I love all Prophets sent by Allah (SWT).

Remained the Same EA

45-I believe that Muhmmad (SAW) is not

Remained the Same

EA author of the Qur'an.

46-Miracles of Prophets are conclusive proof of the existence Allah (SWT).

I am sure that mira-

ES

cles of Prophets are $+\mathrm{EW}$

conclusive proof of their Prophethood.

47-I am satisfied with my spouse.

Discarded

ES

48-I feel that life of all Prophets are a good

Discarded

ES

and positive model to me.

49-I am satisfied with my belief.

Discarded

ES

50-Most of the time, I am optimistic and

I always see the

EW positive about life.

positive side in every

aspect of my life.

51-I believe that all Prophets worked to

I am aware that all

EW lead the people to the straight path.

Prophets follow the path of humanity.

\begin{tabular}{lll}
\hline Ibadah & \\
\hline 52-I always work to raise the prestige of & Discarded & ES
\end{tabular}

Islam.

53-I feel close to Allah (SWT) during Discarded ES solat.

54-I feel that performing solat makes me Discarded ES feel at peace.

55-I tend to perform solat on time.

Discarded ES

56-I always try to pay attention to my pray Discarded

ES (solat).

57-I would never drink the alcohol, even if Discarded

ES

my best friend asked me to do.

58-So far I have committed good deeds for Discarded

ES my parents. 
59-I enjoy reading about Islam.

Remained the Same EA

60-I try to spread the truth of Islam to my

Remained the Same EA all friends.

61-I am thankful to Allah (SWT) for all He Discarded

ES

has done for me.

62-I tend to be self-centred.

Discarded

ES

$63-$ I tend to be indifferent with morality of

Remained the Same

EA my actions.

64-I always remember Allah (SWT) when I am sick.

I always remember ES Allah (SWT) when I +EW am lonely.

65-I tend to seek for forgiveness from Al-

Remained the Same

EA lah (SWT) when I commit sins.

66-I do a mischief in order to get my wishes.

I sometimes do bad

ES deeds in order to get my wishes.

67-I easily feel that Allah`s sign over crea-

Discarded

ES tures is very visible.

68-I go to mosque because it helps me to gain protection and relief.

I go to mosque be-

EW cause it helps me to feel comfortable and relief.

69-I do good deeds immediately after a Remained the Same sinful act.

70-I believe that If I do good things to

Remained the Same

EA others, I will be compensated with good things from Allah (SWT).

71-I believe that the knowledge given to human beings is just like a drop of water in

Remained the Same EA the ocean.

Note. Three codes are provided to indicate the factor(s) that influenced whether to discard, revise, or retain an item (EA=Expert Approval; ES= Expert Suggestions; $\mathrm{EW}=$ Expert Wording).

After the revisions and deletions of items based on the result of item analysis, a total of 27 items were deleted from the instrument, 24 items were remained the same and 20 items were reworded in Integrative Islamic Personality Inventory, as presented in Table 2. 
Consistently, Nursi indicated concerns with each of the items seeking to address that "human beings have the innate capacity to worship to the God, to obey the commands of God" (1930/2003, p.345), these all are reflected in a person's behavior, attitude and feeling. Additionally, prophets are absolute guidance and model to Muslim individuals. It is an understanding of a person how she/he is able to reflect the characteristics of Prophets in her/his behaviors. In order to address above concerns, the following 20 new items, in Table 3, were added accordingly. As for new items, expert community approved to newly added items with other items together.

Table 3 New Items after Expert Revision

\footnotetext{
No New Items

As I see a person weaker than me, I understand I have been

1 richly blessed by Allah (SWT).

2 I certainly feel empty in my life at times.

3 It doesn't much matter what I believe so long as I am good. I work meticulously to live all my life according to Islamic

4 teachings.

5 My whole approach to life is based on Islam.

I have no doubt that Allah (SWT) created me the best creation

6 ever.

7 Even though I am Muslim, I am still a human being.

8 Even though I am Muslim, I still enjoy this life like others.

9 I feel that I have positive feeling towards myself.

I strongly believe that the moral of Prophet Muhammad (SAW)

10 is in total harmony with the Qur'an.

I believe that all Prophets are always tolerant of those around

11 them.

I am very sure that all Prophets used the pleasantest ways to tell

12 people about God.

I am certain that all Prophets are both bringer of good news and

13 a warner.

14 I have no doubt that all Prophets were sent to all mankind.

15 I think sometimes I am behaving against my belief.
} 
16 Sometimes I tend to forget my religion.

17 I feel that I possess good personal characteristics.

18 On the whole, I am happy with myself.

I enjoy going to mosque because of its warm and friendly

19 atmosphere.

20 So far I have fulfilled my responsibilities as a human being.

After revising and eliminating items based on the expert revision and suggestions, 64 items (Table 2 and Table 3) related to integrated Islamic personality comprised the development version of the IIPI. These 64 items were submitted to the pilot study.

\section{Pilot Study}

As refined an initial item pool with content validity in scale development, next step is to administer to samples from relevant populations. Netemeyer and colleagues (2003) define that pilot testing serve the purpose of initially testing for validity and reliability. A pilot study of selected university students was used to determine initial reliability of the measure as part of the validation of this instrument. This pilot testing establishes the strength of the present research and allow it to make any adjustments.

In this pilot testing, researcher only assessed the initial item reliability estimates reliability of instrument (Netemeyer et al. 2003). For pilot testing, convenience samples (e.g., university students) may suffice, so researchers selected major universities, which Turkish students mainly pursue their academic education due to a relevant population of interest. One of them is International Islamic University Malaysia and other is University Teknologi Malaysia.

\section{Participants}

Sixty-four items related to integrated personality were piloted with 57 Turkish students from International Islamic University, Kuala Lumpur and University Teknologi Malaysia, Johor Bahru. The age range of these subjects was between 17 and 34 years. There were 39 males (68.4\%) and 18 females (31.6\%). Major subjects indicated having a mother and father, a few subjects having single and step mother/father as a guardian. 
The complete items of the instrument were subjected to a fullscale reliability test via Cronbach's alpha analysis using the SPSS. The cutoff value of ".70" recommended by Pallant (2011) was used as a guide to determine how reliable were items specified for each construct. The exercise revealed that the entire four construct with 64 items had Cronbach's reliability estimates of 0.92 . This showed that all the items specified for the four constructs were relatively reliable. Table 4 presents the Cronbach's alpha results for four construct.

Table 4 Initial Cronbach's Alpha Reliability Estimates

\begin{tabular}{clrc}
\hline No & Constructs & $\begin{array}{c}\text { No of } \\
\text { Items }\end{array}$ & Cronbach'sAlpha \\
\hline 1 & Tawhid & 15 & 0.84 \\
2 & Hashr & 13 & 0.88 \\
3 & Nubuwwa & 19 & 0.90 \\
4 & Ibadah & 17 & 0.81 \\
\hline & Total & 64 & 0.92 \\
\hline
\end{tabular}

Overall, items aimed at integration of Islamic personality using Western and Islamic perspective demonstrated excellent reliability. In addition, they reflected the theoretical framework of the study. After expert revisions and reliability investigation, the questionnaire might be proceeded to development sample of future study.

\section{Discussion and Conclusion}

This study presents and demonstrates all possible phases and stages of the content validity to develop the IIPI as a prototype of Islamic and Western based scale. It requires however rigorous approach of scale development to come up with substantial and profound dimensions of integrated personality even though it is impossible to surface all possible indicators for it, as inherent in the Western as well as further explicated by the Islamic sources. Nonetheless, the results of content validity and pilot study might provide psychometrically sound evidence of the instrument respectively.

The purpose of this study was to develop an efficient scale that demonstrated preliminary validity and reliability from the outset of this study. It was also a goal of a preliminary study preparing the way for future research studies, which could potentially demonstrate empirical 
support for the adaptive psychological implications of an instrument. As for the underlying factors of IIPI, this study was the first attempt at developing an instrument to assess the integrated Islamic personality. Theoretical explanation and overview of the literature led to the discovery of the proposed constructs, namely Tawhid, Hashr, Nubuwwa and Ibadah. List of item statements were validated in terms of their content by several experts and their reliabilities were tested using both Cronbach's alpha.

To summarize briefly, the items of IIPI were developed by considering the integration of Western and Islamic perspective so that we mainly adapted from the available instruments. Total pool of items was initially 1560 , but limited to 71 items due to the fact that duplicative items were determined to be identical in phrasing or basic intent by discarding one or more items. Following this, expert revision proceeded to validate the items according to the research objective. Based on content validity process and additional consideration to item development, 64 retained items were submitted to pilot study. The reliability of this study indicated the IIPI was strong and reliable and valid. This, thus, indicates that the items of IIPI are significant to proceed to collect bigger sample. Therefore, this is not end stage of instrumentation to fully complete the validity and reliability of the study. This paper is only initial reliable and validity study, suggested to follow the rigorous analysis with construct validity with a bigger sample as for future study. More particularly, researchers suggest to continue with analyze the construct validity of IIPI with similar and different measures. A limitation of this research was the use of fifty-seven participants for pilot study; it would be useful in future research to use bigger sample.

\section{References}

Abu-Raiya, H., \& Hill, P. C. (2014). Appraising the state of measurement of Islamic religiousness. Psychology of Religion and Spirituality, 6(1), 2232. doi:10.1037/a0035082

Abu-Raiya, H., \& Pargament, K. I. (2011). Empirically based psychology of Islam: summary and critique of the literature. Mental Health, Religion \& Culture, 14(2), 93-115. doi:10.1080/13674670903426482

Al-Faruqi, I.R. (1992). Al-Tawhid: Its implications for thought and life. Virginia: International Institute of Islamic Thought. 
American Educational Research Association. (1999). Standards for educational and psychological testing. Washington: American Educational Research Association.

An-Nabahani, T. (1995). The Islamic Personality (4th ed. Vol. 2). Beirut: Dar al-Ummah

Badri, M. B. (1979). The dilemma of Muslim psychologists. MWH London.

Creswell, J.W. and Clark V.P. (2011). Research design and conducting: Mixed methods research (2nd ed.). Thousand Oaks, CA: Sage

DeVellis, R.F. (2003). Scale development: Theory and applications (2nd ed.). Thousand Oaks, CA: Sage.

Duncan, O. D. (1984) Notes on Social Measurement: Historical and Critical. New York, NY: Russell Sage Foundation

Garzanli, R. (2011). Hasir Meydanina Yolculuk Nasil Olacak? Retrieved, 5th June 2014, from: http://www.nurnet.org/hasir-meydanina-yolculuk-nasilolacak/

Hassan, M. (2014). Nursi's Approaches to Morality and the Future of Humanity. International Jounal of Society and Humanities, 4(1), 132-137.

Hair, J. R., Black, J. F., Babin, W. C., Anderson, B .J., and Tatham, R. L. (2010). Multivariate data analysis (7th ed.). New York, NY: Macmillan.

Ismail, N. A. H., \& Tekke, M. (2015). Rediscovering Rogers's Self Theory and Personality. Journal of Educational, Health and Community Psychology, 4(3), 28-36.

Ismail, N. A. H., Tekke, M., Othman, N., \& Al-Hafiz, A. A. R. (in press). Students`Islamic Personality on Ibadah: A Structural Modelling Approach. Procedia - Social and Behavioral Sciences.

McIntire, S. A., and Miller, L.A. (2007). Foundations of Psychological Testing: A Practical Approach (2nd ed.). CA: Sage

Netemeyer, R. G., Bearden, W. O., and Sharma, S. (2003). Scaling procedures: Issues and applications. CA: Sage

Nursi, S. (2003).Sozler (The Words). Istanbul: Sozler(Originally work published 1930)

Nursi, S. (2001). Mesnevi Nuriye. Istanbul: Sozler(Originally work published 1923)

Nursi, S. (2002). Mektubat (The Letters). Istanbul: Sozler(Originally work published 1934)

Nursi, S. (2003).Sozler (The Words). Istanbul: Sozler(Originally work published 1930) 
Pallant, J. (2011). SPSS survival manual: A step by step guide to data analysis using SPSS for Windows (4th Ed.). New Jersey, NJ: Prentice-Hall

Reynolds, C.R, Livingston, R.B, and Wilson, V. (2006). Measurement and Assessment in Education. Boston: Pearson.

Saritoprak, Z. (2008). Islam and Politics in the Light of Said Nursi's Writings. Islam and Christian-Muslim Relations, 19(1), 113-126. doi:10.1080/13510340701770337

Smither, R., \& Khorsandi, A. (2009). The implicit personality theory of Islam. Psychology of Religion and Spirituality, 1(2), 81-96. doi:10.1037/ a0015737

Stephenson, W. (1953). The study of behavior. Chicago:University of Chicago Press.

Tekke, M., Ismail, N. A. H., Adnan, M. A. M., \& Othman, N. (2015). Students ` Islamic Personality On Amanah: A Structural Modelling Approach. Social Sciences \& Humanities, 23(1), 1-10. 